\title{
Human Resource Business Partner as a Source of Conflicts in an Enterprise - Research Results*
}

Stawomir Winch**

\begin{abstract}
The article elaborates on a thesis that development of new functions of the Human Resource Business Partner (HR BP) generates conflicts in three areas of operation of an enterprise: the structure, organizational culture, and goal attainment strategy. A commentary on the concept of the HR BP is provided and the functions propounded within its framework are discussed. Based on qualitative research on three large enterprises in Poland, the following strategies for the introduction of changes in the HR BP are the subject of analysis, that is: maintaining the status quo in power relations, expansion of influence over time, and the policy of small steps. It was concluded that an important factor affecting selection of a strategy is the organizational culture described from the perspective of the concept of Trompenaars and Hampden-Turner.
\end{abstract}

Keywords: HR Business Partner, conflict, organizational culture, organizational goals.

JEL Codes: M12, M54

\section{Introduction}

The emergence of the concept of the Human Resource Business Partner (HR BP) is connected with D. Ulrich who, in the mid-1990s., undertook to describe new functions of HR departments, which contributed to the creation of added value in a company (Ulrich 1997). In his first papers, this value was related to four main roles of HR departments: strategic partner, change agent, administrative expert, and employee champion. Ulrich developed his proposition further in his subsequent papers stressing that the HR BP's activity had greater influence over the key decisions made by companies (Ulrich/Beatty 2001). To describe this role, Ulrich and Beatty used the metaphor of a strategic player. This perspective imposes not only the role of administrator of HR processes on the HR BP but also the roles of structure, designing, and influencing corporate strategy. The HR BP becomes a 'conscience' that decides whether activity the undertaken is in conformity with the values and norms fostered by an organization (Filipowicz 2016; Popieluch 2018). The HR BP is also supposed to enable professional development (as a coach), help initiate and introduce organizational changes (as an architect and builder), promote desired attitudes and influence employee engagement (as a leader), resolve conflicts, and take care of information flow (as a facilitator) (Ulrich/Younger/ Brocbank 2012).

* Received: 10.02.2020, accepted: 17.07.2020, 1 revision.

** Stawomir Winch, Dr. habil., Associate Professor, SGH Warsaw School of Economics, Institute of Management. Email: slawomir.winch@sgh.waw.pl. Main research interests: Organizational culture, Leadership, Negotiations, HR business partner. 
The concept of the HR BP has been a response to the growing role of employees as an element of enterprise competitive advantage. Businesses started to compete for the best qualified specialists and focused on boosting involvement of all staff and their identification with company activities. Employment costs have increased, and the traditional role of HR departments, i.e., concentration of the administrative function, has proven to be insufficient for business processes. These processes require, among others, knowledge in the field of analysis of employment costs, staff development in the context of business strategy, and labour market trends. Some authors even claimed that the future of HR will be located outside the HR area (Ulrich/Schiemann 2015). The role of HR department staff started to evolve from administrative functions to management. They became members of boards in establishing company strategies, also from the perspective of personnel strategy. Consequently, the name of the department changed into HR BP's, which highlights both its substantive role and its position in the organizational power structure.

Such a description of the HR BP's functions may raise doubts because of conflict arising between the roles the HR BP serves. On the one hand, the HR BP is supposed to be the leader of changes and, on the other hand, the spokesperson for the employees. Usually, there are groups that lose the chance to advance their interests when changes are being introduced and ones that benefit from it. Which group the is HR BP supposed to be the spokesperson for? Another issue is validation of the role of the 'conscience' that decides the conformity of activity with the values and norms that are followed. As a general rule, the HR BP's stance is ancillary to the management board of the company. How can one expect the HR BP's to be loyal considering their place in the organizational structure and assumed loyalty towards the management board? Performing the designated roles of the HR BP requires having competencies in the following fields: the law, financial and strategic analysis, marketing, the technology of social mechanisms shaping employee attitudes, etc. It is difficult to imagine that it could be easy to find people with such varied competencies, who would, at the same time, take part in the decision-making process. And even if such people were found, why would the members of the management board share power with them? The issue of responsibility also remains unsolved, which in practice can be diffused among various people. A way out of this situation is the proposition to create coordination centres or place the HR BP's in individual organizational divisions, etc. (Filipowicz 2016). Taking over new functions does not automatically imply taking over the role of a business partner. This role requires, among others, resources that are not easily available for the others. It seems that the 'business partner' term is supposed to raise the prestige of HR departments, rather than meet the real requirements of the role of a business partner.

Despite criticism, HR departments in Poland (especially in international corporations) more and more commonly take the name HR BP or use transnational 
names but carry out the above-mentioned functions. It seems that the reason for the HR BP's expansion should be sought in the dynamic changes that organizations are undergoing due to the development of new technologies. There is need for coordination of these changes and the HR BP concept addresses this need. It is possible that this is an effect of a fashion in management, which is fuelled by consulting companies. Such a phenomenon was observable with the concepts of reengineering or turquoise organizations. Nevertheless, the HR BP slowly became reality in management practice, and it is worth reflecting on this phenomenon from a scientific point of view. It is significant since the new HR BP functions became sources of conflict within commercial organizations.

The aim of this article is to analyse three sources of conflict related to the functioning of the HR BP: the organizational structure, the culture, and business objectives.

Multiple other sources could be indicated, e.g., interpersonal relationships, socio-demographic differences or competencies. The article focuses on the former due to the fact that they were indicated by the respondents in interviews carried out in 2019 by a team supervised by Tabor-Błażewicz within the framework of statute tasks of the Warsaw School of Economics (Tabor-Błażewicz 2019). The study was qualitative in character. The research sample comprised the representatives of two international corporations (i.e., a bank and a consulting firm) and a state-owned company. All these commercial organizations have been functioning in the Polish market for over twenty years and each employs more than a thousand people.

\section{Research Methodology}

Qualitative research, which we work on in this article, is based on analysis of phenomena in their natural social context, while stressing the way reality is perceived by the participants themselves (Nachmias/Nachmias 1996; Babbie 2015).

This article adopts the symbolic-interpretive perspective where the researcher refrains from analysing phenomena while already having a research problem in mind or hypotheses formulated earlier based on a theory (Gibson/Morgan 1979). Research problems and hypotheses emerge in the course of field experiments as well as from the collected empirical data that do not enable statistical verification of hypotheses but indication of relationships between variables on an empirical basis (Glaser/Strauss 2017). The qualitative approach involves initial conceptualization of a research problem; however, it merely serves as a general indication of the empirical material that is sought after. It is recommended to collect the material by various means (e.g., through interviews, observation, organizational stories) and limit the conceptualization of notions. Qualitative research is composed of three stages: collecting research material, interpreting it, and recording the findings (Kostera 2007). According to the assumption presented 
assumptions, a general research question has been formulated: in what way are the conflicts caused by new HR functions resolved in the context of organizational structure and culture, as well as methods of reaching company goals?

In analyses of this type, the issue of representativeness of the research sample does not decide the value of the conclusions that are drawn from it. These conclusions do not serve the role of far-reaching theories. Inferring is limited to the enterprises that they are concerned with. They only signal the existence of an ill defined probability of occurrence of the observed dependencies in other companies marked by similar characteristics. The symbolic-interpretive perspective presupposes constant changes and instability of the reality and so an attempt to generalize the results becomes even more unjustified. This is a general reflection on empirical research regardless of its character - the researcher presents a certain record of the past and the fact that it continues to exist in the present time is a more or less justified assumption. The representativeness of qualitative research tends to be understood as the goal of achieving representativeness of the substance of the study. The researcher is interested in how a given person perceives reality and the uniqueness and inimitability of this perception are important. Thus, the more there are various people, the more there are observations concerning the aspects of the phenomena under examination (Kostera 1996: 14). Work comes to an end when the researcher is convinced that all the possible material for analysis has been collected. Hence, the use of as many research methods as possible in the course of qualitative research is advocated: (participant and non-participant) observation, (structured and unstructured) interview, desk research, analysis of stories or bibliography, etc. In this study, a semi-structured interview was used to initiate the research process that will be continued over the subsequent years.

The questionnaire for the interview covered the following topics: placement of the HR department in the corporate structure, the functions of the HR department and conflicts with other organizational units arising from them, the HR strategy, talent and diversity management programme, and organizational culture.

The article presents qualitative case studies. This method was selected based on the interests of the researcher who freely chose data collection methods. In this elaboration, these are interviews with people holding managerial positions in HR departments. The strong point of such analyses is the possibility of presentation of a given problem from the point of view of its varied conditioning. This opens up the possibility of deepened interpretation of a phenomenon, which emerges in cooperation with the people that take part in it. In consequence, the researcher obtains a subjective account provided by the representative of an organization, which is the weak point of the method. 
The phenomena that are being presented are described instrumentally (Stake 2009: 627) since the description of a particular enterprise is not for the sake of the enterprise but serves to broaden knowledge of a more far-reaching phenomenon and to draw general conclusions. The interviews were held in several companies, which allows categorization of the study as a collective and instrumental case study simultaneously. This offers a richer basis from which to draw conclusions.

On their approval, the respondents' replies were recorded by the members of the research team which carried out its final analysis from the transcript of the records. Interviews were recorded using dictation machines. After the interviews were transcribed by the members of the research team, the recordings were deleted so to make it impossible to identify the firms and the respondents.

Interviews were carried out with employees senior positions in HR departments. Each interview took about one hour. The interviews were conducted by academic employees of SGH Warsaw School of Economics, based on previously prepared guidelines. They covered topics such as the scope of responsibilities, barriers to introduction of new functions of the HR BP, and the role of HR in the management process. Contacts with respondents were initiated by SGH graduates. Companies with various ownership structures were selected: entities with majority state ownership, international corporations with dispersed stock ownership, financial institutions with the majority ownership of two stockholders. It was assumed that the ownership structure differentiates the way conflicts are resolved in the analysed aspects (i.e. structure, culture and objectives of an organization). The aim of the analysis of the interviews was to understand the subject phenomena through their interpretation in the context of changes occurring in an organization. The statements were not coded, and the role of the researchers was to interpret the phenomena reported by the respondents. It is a very subjective analysis, where the interpretation of responses is significant and research problems are usually formulated after the end of the research process. This is one of the objections to this type of analysis. However, such an analysis does not claim to provide a generalization for the phenomena examined. It focuses on a description of individual cases. It does not exclude formulation of hypotheses that can be verified by further quantitative research.

\section{Structural Sources of Conflict}

The corporate structure and the resultant scope of power have been the traditional sources of conflict in organizations. As noticed by Crozier and Friedberg (1987), a specific characteristic of such a structure is control of the sources of uncertainty: access to information, relationships with the key stakeholders, possession of crucial skills, and compiling rulebooks (Crozier/Friedberg 1987). The above-mentioned authors were the precursors of the analysis of organizations 
from the point of view of the game employees (i.e., actors) play to hold resources enabling them to control the sources of uncertainty (i.e., power). Crozier and Friedberg (1987) created an image of an organization as having two structures. In the first, formal, one, the decision-making process unfolds within the framework of established and approved procedures. In the second, informal, one, emotions as well as calculation regarding the manner of advancing the interests of individual groups of employees are more significant. The key role is played by the skill of making alliances that are necessary to attain the goals of individual groups.

Some of the areas of uncertainty, and so the sources of power, are employee recruitment, administration of remuneration, social affairs, etc. Formally, they have been assigned to HR departments and tend to be associated with so-called hard HR. There are also some elements of soft HR among them, which have been brought into organizations, and sometimes even elements of inspiration, employee training, talks with employees, tests of competencies, engagement, etc. Over many years, boundaries of responsibility have been established in organizations between HR departments and the other organizational units. The domain of action of the former is administration of HR affairs and satisfying other units' needs concerned with recruitment or employee training. It is much less common to expect these departments to carry out employee attitude surveys, manage talent, or resolve interpersonal conflicts.

The practice of the HR BP also inevitably implies a conflict of interest among the roles fulfilled in an organization. On one hand, leaders of HR departments are supposed to indicate the development needs to be satisfied (e.g., purchase of technology), on other hand they should boost employee involvement (e.g., by various training courses). Thus, a natural conflict arises, the subject of which is redistribution of profits among various areas of enterprise activities. The HR BP department represents interests related to both economic efficiency and staff development (Miller 2017).

The domain of the management is, among other things, designing a strategy based on support provided by other organizational units (dealing with marketing, finances, etc.). It may so happen that some activities alter such boundaries through informal games (e.g., of financial support for training, remuneration, motivating instruments, employee evaluation criteria) within an organizations. Such a model of operation of HR departments is deeply rooted in organizations' traditions, which is highlighted in the respondents' replies:

The support functions are lumped together; HR, finance, and IT; and so, I suppose, HR is sometimes seen here more as a support function rather than a strategic consultant.

(Interview 1) 
I am the Head of the Human Resources Management Department and the department is divided into three sections: the HR Administration Section, that is, typical HR; the Recruitment Section, and the Development and Employer Branding Section.

(Interview 3)

In our company, the HR structure is not involved in strategic management at Management Board level; there is no HR representative among the boards members; whereas the Human Capital Division reports directly to the President. Our structure is vast and scattered all over the country. And so, the units of the Human Capital Division are also scattered all over Poland. In the Headquarters, we pursue the strategic goals of the whole group of companies and there is a part devoted to the HR policy within this strategy; whereas the role of the Human Capital Division is not quite setting the direction but making things happen based on the strategic directions. The $H R$ Department is more supportive than strategic.

(Interview 4)

It is worth stressing that in theoretical concepts, the term 'human resources' tends to be used less often as it suggests treating employees as objects. Instead, the use another term is advocated, i.e., the 'human capital' (which is the case in interview 4) and currently the HR BP. In practice, traditional names are still in use. It should be assumed that it is not the reflection on the nature of employee relationships that underlies the use of these names but habit. Thus, one may suppose that this habit is also transposed to the way the functions of the HR departments are perceived.

The modern concepts of the HR BP stress the strategic role of the HR department (Popieluch 2018: 12). Thus, they transgress the areas of influence established earlier and enter the territory reserved for others (e.g., marketing or finance), while reaching the highest levels of management (Mitchel/Gamlen 2017). The decision-making process in the companies under examination takes place in line with the logic followed by bureaucratic organizations, that is, based on formalized procedures. On the one hand, traditional division of influence applies and an expectation to serve the role of a 'strategic partner' builds up but no formal instruments of exerting power are provided. In line with the concept of Crozier and Friedberg (1987), such a situation creates informal influence on the decision-making process. The second - informal - structure of influence in an organization grows in importance.

We work directly with the members of the board; each of us is assigned to one of the board members and so we have a very strong position here. They value our opinion highly but it's this particular board member. I am exposed to just one and not the whole management board. We are beginning to work on making them see that we are a team that can support the whole board and not just in a 1:1 relationship. And then there are loads of people reporting to this board member and who knows to what extent they actually see us as such an advisory, strategic arm, etc. and to what extent they still see us as support. There is constant balancing and we need to heavily lean on building a relationship all the time.

(Interview 1)

The Directors go straight to HR and speak to the Head of HR or the Head of Recruitment, etc. We can't avoid that either because if I know Krysia, I will go to Krysia and leave out Janek on 
the way, and if I actually fully trust this Janek, I know his competencies, role, etc., then I will probably go to Janek too.

(Interview 1)

Assigning formal authority in the corporate structure to HR departments becomes a requirement that must be satisfied in order for them to perform their extended functions arising from the HR BP concept. One of the respondents indicates so:

Talent and HR programmes must be carried out at the management level. (Interview 2)

In my previous company, HR was a strong unit where the Head of the HR was a board member and so we were really at the top and played a more strategic role.

(Interview 1)

Organizational structure shapes blurred decision-making areas, which fosters shifting responsibility.

Right now, there is a somewhat matrix structure in the organization as, on the one hand, we have the Polish structure and, on the other hand, the international one. Therefore, the Polish Head of $H R$ reports to the President, or in fact the Management Board, but also like in a matrix to the Regional Head of HR for Europe so it's a dual structure.

(Interview 1)

There are two speeds, everything has been great on the outside but inside there are no links between individual cells (...) the Presidents sign because why not? They think the Head of the department knows what he or she is doing. They come to me and, you know, I wanted to but the 'bitch' from HR didn't give you a rise.

(Interview 2)

And so, when I do or say something, I hear: we had that in 2014 but it didn't last. It didn't because changes and trainings are cool but then nothing happens. Leadership trainings are awesome but if no one evaluates these competencies, then they don't exist.

(Interview 2)

The respondents have their image of an ideal organizational structure, that is, a structure where extended HR functions can be carried out.

The HR department reports directly to the President of the Board (...); there are five board members in the structure and they have parallel functions and one of them is the President of the Board but he is also in a parallel position and there is the HR Department within his division. We are lucky that our HR Department is very deeply involved in the formulation of the business development strategy and that we serve a strategic role advising in all important matters.

(Interview 3)

\section{Culture as a Source of Conflict}

From the perspective of a functional paradigm of management, the role of organizational culture - similar to other factors - is to maintain the existing system over time (Tromperaars 1993; Tromperaars/Hampden-Turner 2005; Hofstede/ Hofstede/Minkov 2010). The functional-structural approach highlights be- 
havioural patterns related to one's position in the corporate structure. There is no denying the existence of a system of values and norms common for the whole community but it is noted that depending on the organizational level, people are characterized by a different status and mentality as well as using different means to cherish the values. The relations between the culture and the environment in which a company operates are also stressed.

Without going into detail regarding theoretical stances (as it would go beyond the scope of this report), the point of departure is assumed to be Schenplein's definition of organizational culture, which claims that these are the 'values, norms, and beliefs that are widely accepted in an organization and which form a system' (Sułkowski 2008: 13).

Values are related to norms, that is, ways to cherish the values and rules shaping employee behaviours, which take the form of 'dos and don'ts'. There is also the issue of the communication of values and norms. It takes place through stories (or legends), symbols, customs, etc.; and in the case of companies, ethical codes, good practices reports, etc. can be added to the list.

Uniform organizational culture may only be found in micro organizations. It seems that in large companies with extended structures, there are multiple systems of values and norms, which are sources of conflicts among employees. Trompenaars, and Hampden-Turner (2005) proposed a typology of cultures based on two criteria: equality vs hierarchy and person vs task. They singled out four types of culture: the Family culture, the Incubator culture, the Eiffel Tower culture, and the Guided Missile culture. The Guided Missile and Family cultures were the most pronounced in the companies under examination.

In the Guided Missile culture, performance of ongoing tasks comes into focus. This type of culture is sometimes referred to as the corporate culture. The dilemma of group interest vs system's interest is usually resolved to the advantage of the group. Organization understood as a 'common good' exists only in the declarations and not actual prerequisites for actions - exclusively the interest of the individual or the group of which he or she is a member is taken into consideration. The attitude of a 'political player' dominates and such a player may be loyal towards their party, but it does not rule out him taking actions involving games and manipulation when dealing with the group. Generally, conflicts usually unfold secretly, and temporary alliances of interest groups are formed.

It is a typical corporation, perhaps even more brutal; I guess the reason for that is, among other things, the fact that there is such high turnover after all (...). There are constantly new faces, new people, and so there are no relationships that would humanize this corporation a bit (...). Here we have - though our bosses don't want to talk about it - a total corporation.

(Interview 1)

In this type of culture, interpersonal relationships based on emotions disappear making room for effective goal attainment (i.e., instrumental relationships). The 
former does not negate the existence of the latter. In this kind of culture, the organization is oriented to the present time (Winch 2016).

For companies oriented to the present time, the here and now is what matters the most. Such an orientation fosters the development of instrumental relationships among employees. A person is thus as useful as he or she is capable of pursuing the current interest of the group. In the culture of the present time, individual working time is important, that is, the managers allow employees to work on an individual basis and notice the contribution of each person. Under such circumstances, the expression 'time is money' is treated literally and all deviations from the schedule are perceived as threats. Focus on the present time is marked by an approach to performing tasks based on the mindset that 'the end justifies the means'. It seems that in a company oriented to the present time, the character of the employee-company relationship is best reflected by the saying 'a good servant must have good wages'. In this time perspective, a capable manager becomes indispensable. Such a culture is fostered by management by objectives that precisely define success criteria over a maximum period of one year. The present time implies rewarding current successes, focus on achieving successes that are spectacular, drawing up short-term plans, and maintaining structures to the extent they work towards the established goals.

A lot of HR projects are carried out over the course of many years. These include talent management, loyalty programmes, etc. In the Guided Missile culture oriented at the present time, this is impossible due to the very nature of this culture. The above-mentioned programmes require mutual trust and relationships based on emotions, which stand in opposition to the nature of that culture. This type of culture is accompanied by high labour turnover, which makes it impossible to carry out long-term HR plans oriented at specific employee groups.

The HR staff changes habitually. Turnover is very high, and it is often an issue really.

(Interview 1)

The need for closer, that is, emotional relationships is noticed by the respondents.

I think direct contact, which is close and trustworthy, is very important; I rely on it. I've been building such relationships for years and people come to me for advice or to discuss certain things. It is very difficult because there is so much current stuff going on, so many topics that come up every day that it really is difficult for us to be such a strategic partner; though we truly work hard to make this happen.

(Interview 1)

The opposite of the Guided Missile culture is the Family culture: there are emotional relationships and a clearly defined organizational hierarchy. Identification with the employees leads to the development of a group identity as well as strong bonds among employees, which arise from group solidarity. Normative trust dominates within the groups, which is based on believing in following 
identical norms and values that underlie behaviours in an organization. An important criterion shaping this type of organization is awareness of existence in time - continuation - of a certain tradition of attitudes. It is an organization based on strong bonds among people with simultaneous appreciation of hierarchy. It appears that in this type of culture, perennial HR plans stand a chance. One of the respondents indicates this:

We decided to devise different types of programmes and initiatives that foster satisfaction from work. We are very close to our employees (...) they often come to us with some situations and ask for support, e.g., in dealing with something concerning their boss, so these are issues that show that they have huge trust in us and that they know that we're going to address their problem in order to solve it and not stigmatize the person who reports it.

(Interview 3)

The Family culture does not rule out orientation to the present time.

We are more of a start-up and we have to act really fast because we have very short decision time available.

(Interview 3)

Negative consequences arising from time orientation (i.e., limitation of the possibility to carry out long-term plans) are nullified by the small power distance which arises from the culture. In Hofstede's concept, the power distance reflects the approach to inequality, which dominates in a given culture (Hofstede et al. 2010). In cultures that treat inequality as something natural, there is large power distance. There is assent to a hierarchical organizational structure. When the power distance is large, employees lose control over their future because the 'power elite' holds it. As a general rule, in this type of company, there is oneway communication that takes place top-down. Usually, these are formalized companies where procedures are decisive in everything. On the one hand, it is claimed that the employee becomes an object (which is a frequent accusation against such companies) and not an entity in the decision-making process and, on the other hand, organizations of this type offer a sense of security and stabilization due to the predictability of the decision-making process.

In organizations where the power distance is small, inequality among employees is less acceptable. The inequalities are not concerned with the material dimension, such as salaries or access to information related to one's position, etc. There is assent to an uneven distribution of resources in the scope of one's possessions, responsibility, and the risk taken. The lack of acceptance of inequalities is concerned with interpersonal relationships, that is, possibilities for voicing critical opinions or discrimination based on one's social role. In companies where the power distance is small, there is constant exchange of information among people and among various levels of the company, whereas uncertainty is alleviated through discussions and exchange of opinions. Large power distance and the resultant hierarchy may give people a sense of security. Small power distance may also meet this need as there is a possibility of having ongoing contact 
with the superior and receiving support in solving professional issues. The following report may testify to a small power distance in one of the companies under examination.

Although we have an extensive structure just as in any bank, we don't have the traditional power distance. We all address each other by name, our members of the management board very often interact with the experts and people in lower positions so any employee may definitely approach us. There is no hierarchy here and we don't even want to have such a hierarchy because it makes processes take more time. Anyone may come to us directly with their problems or needs and we try to respond to any such need appropriately and address it adequately. It is very important for us; as the HR Department we really see our role and mission as a department that stays with the employee throughout his or her whole life in our company - we are close; we're by their side.

(Interview 3)

Development of an effective information flow that reduces the scale of conflicts among organizational cells plays a major role in creating the culture of small power distance.

We are, in fact, a department that solves conflicts arising among various employees or structures in our company. Inherently, we try to alleviate such situations, but we also explicitly inform how important communication is as it ends the majority of conflicts among feuding departments. Often conflicts arise from the lack of knowledge, incorrect information, misinterpretation of someone's intentions or speaking in an inappropriate tone in emails that we read because, as we know, a corporation mainly communicates via electronic mail. We prioritize - within the framework of the HR strategy as well - the development of internal communication that, first and foremost, creates awareness of how important communication is and how important it is to speak out, if we have any problems so that others can interpret our attitude and behaviour in some way. (Interview 3)

In cultures marked by a large power distance, a scope of entitlements, privileges, etc. is established, which is accepted by employees. Disturbance of this order by new HR programmes becomes a source of conflict and tension among employees.

Talent programmes provoke divisions in the organization and quite unnecessarily. Experienced employees are overlooked, and only new ones are taken into consideration because they are the talent, the future, the potential. It's a mistake; a person should be seen as having a potential or talent at variaus ages and in various places, etc.

(Interview 2)

\section{Organizational Goals as a Source of Conflict}

The classic definition of a company highlights its economic effectiveness and claims that 'It is an entity conducting economic activity and striving for the satisfaction of the needs of other social actors (i.e., people and/or other institutions) by way of manufacturing products and/or rendering services; while its activity is motivated by the desire to obtain financial benefits and it is ran at the sole risk of the owner(s)' (Sudol 2006: 36). This perspective is related to a conservative management paradigm. Within the framework of this approach, individual needs and motivations are stressed, however, they cannot be fulfilled without other so- 
cial actors. If new ideas contribute to economic viability, the essence of a company is preserved - that is, generation of profit. Otherwise, the commercial organization ceases to exist, or its existence becomes dependent on state aid. From this perspective, it is advocated that it is necessary to separate the main function of a company (i.e., generation of profits) from pursuance of other ideas. It has nothing to do with a negative approach to acting to the benefit of the society and the environment. Generally speaking, the conservative paradigm sees threats to employees in blurred organizational functions and excessive interference of the state in their everyday operations (Scruton 2012).

One of the aims of a company is advancement of the interests of the owners, which is guaranteed through coordination of the activity of others. The key mechanism of regulation, as well as the criterion of effectiveness becomes economic calculation. It does not rule out fulfilment of the needs of others, but its limit is the financial prevalence of profit over costs.

Extension of the functions of HR departments through new programmes of recruitment, onboarding, and development of employees raises questions as to the costs of this type of undertaking. These are voiced in the respondents' comments.

We are an organization that is first and foremost oriented at generation of profit and everything needs to have its structure.

(Interview 2)

Frequently, losing a good employee means that we need to hire a new one who will be $30-40 \%$ less experienced, which is tantamount to paying half as much for this employee than for the one we are losing.

(Interview 3)

We are a very dynamic company that keeps close track of its cost effectiveness. Therefore, we decided to split the HR functions and establish three departments. Each department has its recruitment supervisor, HR supervisor, and soft HR that carry out certain projects or manages training and are in contact with them anyway. We do't have a single function and we do 't plan on implementing one. Experience has shown that such a division is much more effective for us.

(Interview 3)

The quotes delineate a fundamental conflict between the traditional role of HR departments and the HR BP concept. According to the traditions of Polish commercial organizations, HR departments are seen as units making the decisions of the management board happen within the framework of a broadly understood HR policy. It is not always consistent with the interests of employees, especially regarding remuneration, career paths, or staff reduction. The criterion that solves the dilemma between the,good of the employees, and 'good of the company' is economic calculation. In this context, management practice is closer to the conservative paradigm.

One of the important new functions of the HR BP is creating the employer image. It has been assumed for a long time that employees are one of the factors in 
gaining competitive advantage. Therefore, there is a need to attract the most talented people and, what is more, to retain them in organizations for as long as possible (Wilcox 2016). One of the instruments for the achievement of these goals is the circulation of information. The point is not only to perform professional tasks, but also to diagnose social attitudes or areas of conflict.

The analysis of the interviews makes it possible to diagnose the situation, at least from the perspective of opportunities and risks posed by new solutions. Theoretical reference comprises concepts of organizational change and organizational behaviour (Konopaske/Ivancevich/Matteson 2016). Practical reference is the statement of interests and objectives of individual groups. The methodology of quantitative research excludes the possibility of statistical analysis and simultaneously gives an opportunity to learn about new attitudes to organizational change.

\section{Conclusions}

The interviews that were carried out show three strategies (or ways) of implementing the extended functions of HR departments and the resultant conflicts. They are all carried out within the framework of their traditional placement within organizational structures and they are service functions attending to other units.

The research question is about the ways of resolving conflicts caused by the new HR functions in the context of organizational structure and culture, as well as ways of pursuing company goals. This objective was achieved by distinguishing three ways of conflict resolution: avoiding, the informal game of different interest groups and evolutionary change of organizational structure.

The direction of the first strategy is set by a saying 'let it be the way it was', which is characteristic for the interview in company no. 2. Propositions of new functions meet with opposition even within the HR department itself. The reason for that may be negative previous experiences, fear of accepting responsibility or reluctance of others to share power in the enterprise. As far as this strategy is concerned, conflict is resolved through procedures and instructions within the superior-subordinate relationship.

The second strategy unfolds according to the saying 'in for a penny, in for a pound', where more or less formalized procedures influence the decision-makers. In interview no. 1 , it is visible that decision-makers are influenced through the creation of interpersonal relationships whose aim is the demonstration of competencies related to business strategies that go beyond the traditional HR roles. Within the framework of this strategy, conflicts regarding HR functions tend to be solved outside the formal procedures. The key role is played by rela- 
tionships and alliances built up based on these relationships with people higher in the decision-making hierarchy.

The third strategy is very similar to the second one and its direction is reflected by the metaphor 'little strokes fell great oaks'. This is, first and foremost, the company represented in interview no. 3. Similar the case with the second strategy, this one is based on establishing relationships. The difference between these companies is the characteristics of the organizational culture. Interview no. 2 shows dominance of the typical indicators of the Guided Missile culture oriented in the present time. In interview no. 3, the present time is also the key factor in settlements with employees, however, development of lasting emotional relationships is also important, while the power distance is small.

A common element in each strategy is focus on the economic profit and loss account related to the performance of HR functions.

It seems that future research on conflict linked to HR functions should concentrate on organizational culture as an opportunity for or threat to the new undertakings of the HR departments.

The cases described are in line with the concept of conflict resolution in organizations. Their traditional source is power. New functions of the HR BP raised the significance of HR department staff, making them an important player in the rivalry for influence within an enterprise. An important circumstance of this rivalry is the organizational culture, determining behaviour of people and their use of the influence tool.

Consequently, further direction of studies of conflicts related to the HR functions should focus on the organisational culture as an opportunity or a threat for the new functions of HR departments.

\section{References}

Babbie, E. (2015): The basic of social research. Boston: Cengage Learning.

Crozier, M./Friedberg, F. (1987): Człowiek i system [Man and System]. Warsaw: Państwowe Wydawnictwo Ekonomiczne.

Glaser, B./Strauss, A. (2017): The discovery of grounded theory: Strategies for qualitative Research. New York: Routledge.

Gibson, B./Morgan, G. (1979): Sociological paradigms and organizational analysis. London: Heinemann.

Hofstede, G./Hofstede, G./Minkov, M. (2010): Cultures and Organizations. Software of the Mind. New York: McGraw-Hill.

Filipowicz, G. (2016): HR Business Partner. Koncepcja i praktyka [HR Business Partner. The Concept and Practice]. Warsaw: Wolters Kluwer.

Konopaske, R/Ivancevich, J./Matteson, M. (2016): Organizational Behavior and Management. New York: McGraw-Hill. 
Kostera, M. (1996): Postmodernizm w zarządzaniu [Postmodernism in Management]. Warsaw: Państwowe Wydawnictwo Ekonomiczne.

Kostera, M. (2007): Kultura organizacji. Badania etnograficzne polskich firm [Organizational Culture. Ethnographic Studies on Polish Companies]. Gdańsk: Gdańskie Wydawnictwo Psychologiczne.

Miller, T. (2017): Human Resources as Business Partner. New York: Business Expert Press.

Mitchell B./Gamlem, C. (2017): Conflict Resolution. New Jersey: Career Press.

Nachmias, C.F/Nachmias, D. (1996): Research methods in the social sciences. London: Arnold.

Popieluch, K. (2018): HR Business Parter - rola, funkcje, zadania, kompetencje [HR Business Parter - Role, Functions, Tasks, and Competencies], in: Popieluch, K (ed.): HR Business Partner. Warsaw: Wydawnictwo Naukowe PWN, 11-29.

Scrutton, R. (2012): Green philosophy: How to think seriously about the planet. Ondon: Atlantic Books.

Tabor-Błażewicz, J. (2019): Współczesne funkcje działu personalnego. Raport z badań statutowych $\mathrm{KZiF} / \mathrm{S} / 53 / 18$ [Contemporary Functions of the HR Department. Report on Statutory Research $\mathrm{KZiF} / \mathrm{S} / 53 / 18]$. Warsaw: SGH Warsaw School of Economics.

Trompenaars, F./Hampden - Turner, Ch. (2005): Zarządzanie personelem w organizacjach zróżnicowanych kulturowo [HR Management in Organizations Varied in Terms of Culture]. Kraków: Oficyna Ekonomiczna.

Stake, R. (2009): Jakościowe studium przypadku [Qualitative Case Study], in: Denzin, N./ Lincoln, Y. (ed.): Metody badań jakościowych [Qualitative Research Methods], vol. I. Warsaw: Wydawnictwo Naukowe PWN.

Sudoł, S. (2006): Przedsiębiorstwo [Enterprise], Warsaw: Polskie Wydawnictwo Ekonomiczne.

Sułkowski, Ł. (2008): Czy warto się zajmować kulturą organizacyjną? [Is It Worth Studying Organizational Culture], in: Zarządzanie Zasobami Ludzkimi, 6, 9-25.

Ulrich, D. (1997): Human resource champions: The next agenda for adding value and delivering Results. Boston MA: Harvard Business School Press.

Ulrich, D./Beatty D. (2001): From partners to players: extending the playing field, in: Human resource Management, 40, 4, 293 -307.

Ulrich, D./Younger, J./ Brocbank, W. (2012): HR from the outside in: Six competencies for the human resources. New York: McGraw Hill.

Ulrich, D./Schiemann, W. (2015) The rise of HR, Alexandria: HR Certification Institute.

Wilicox, M. (2016) Effective Talent Management, New York: Swales \& Willis Ltd.

Winch, S. (2016): Substytuty przywództwa w przedsiębiorstwie [Leadership Substitutes in a Company]. Warsaw: Oficyna Wydawnicza SGH. 